2013

\title{
Asset Pricing, Jump Risk, and China's B-Share Discount Puzzle
}

Haigang Zhou

Cleveland State University, h.zhou16@csuohio.edu

John Qi Zhu

Fudan University, qizhu@fudan.edu.cn

Follow this and additional works at: https://engagedscholarship.csuohio.edu/bus_facpub

Part of the Finance and Financial Management Commons

How does access to this work benefit you? Let us know!

\section{Publisher's Statement}

acknowledgement in the form of a full citation must be given to the journal as the original source of publication, together with a link to the journal webpage and/or DOI as soon as they are available.

\section{Original Published Citation}

Zhou, H., Zhu, J. (2013). Asset Pricing, Jump Risk, and China's B-Share Discount Puzzle. International Journal of Financial Services Management, 6(4), pp. 352-366.

This Article is brought to you for free and open access by the Monte Ahuja College of Business at EngagedScholarship@CSU. It has been accepted for inclusion in Business Faculty Publications by an authorized administrator of EngagedScholarship@CSU. For more information, please contact library.es@csuohio.edu. 


\title{
Asset pricing, jump risk, and China's B-share discount puzzle
}

\author{
Haigang Zhou
}

Department of Finance, Cleveland State University, Cleveland, $\mathrm{OH} 44115-2214$, USA

Email: h.zhou16@csuohio.edu

\section{John Qi Zhu*}

Department of Finance, School of Management, Fudan University, Shanghai 200433, China Email: qizhu@fudan.edu.cn

*Corresponding author

\begin{abstract}
This study examines whether differential systematic risks, along with other competing explanations, account for cross-sectional variations in $\mathrm{B}$ share discounts in China, using both cross-sectional and panel data analysis. Results show strong evidence that variations in A-share systematic risks are positively related to variations in B-share discount after controlling for various competing explanations. No evidence shows a correlation between variations in $\mathrm{B}$-share systematic risks and variations in B-share discounts. These findings survive various robustness checks. The study further decomposes total systematic risk into continuous and jump components. Regression results indicate that variations in $\mathrm{B}$-share discounts are explained mostly by variations in systematic continuous risk but not by variations in systematic jump risk.
\end{abstract}

Keywords: jump risk; China's B-share discount puzzle; realised volatility; Brownian; financial services management; systematic risks.

Reference to this paper should be made as follows: Zhou, H. and Zhu, J.Q. (2013) 'Asset pricing, jump risk, and China's B-share discount puzzle', Int. J. Financial Services Management, Vol. 6, No. 4, pp.352-366.

Biographical notes: Haigang Zhou, $\mathrm{PhD}, \mathrm{CFA}$, is an Associate Professor of Finance at the Monte Ahuja College of Business. He received his $\mathrm{PhD}$ in Finance from the University of Nebraska-Lincoln in August 2006, and was awarded the Certified Financial Analyst (CFA) charterholdership in April 2006. He has been teaching undergraduate, MBA and doctoral courses at CSU since August 2006. His research interests are in investments, corporate governance, executive compensation, international financial management, and behavioural finance. His research has been published or forthcoming in many premier finance journals and presented at top finance conferences internationally. 
John Qi Zhu is an Assistant Professor of Finance at School of Management, Fudan University. He is also a fellow of Wharton Financial Institution Center. He received his $\mathrm{PhD}$ degree from Emory University in 2007. His research focuses on empirical asset pricing issues in the global and Chinese financial markets and has been published in various finance journals. He is currently teaching the valuation and financial econometrics courses in the Master of Finance programmes. He has been awarded grants from the National Science Foundation of China and as a Pu Jiang Scholar from Shanghai Municipal Government.

This paper is a revised and expanded version of a paper entitled 'Asset pricing, jump risk, and China's B-share discount puzzle' presented at the 'Southern Finance Association Meeting', Key West, FL, November 2008, and Financial Management Association Meeting', Reno, NV, October 2009.

\section{Introduction}

In most segmented stock markets, stocks that are available to both domestic and foreign investors are typically priced at a premium compared to otherwise identical shares available only to domestic investors (Hietala, 1989). However, in China local A-shares restricted to domestic investors are priced at a premium relative to $B$-shares available to both domestic and foreign investors. ${ }^{1}$ Different explanations are offered to explain the B-share discount puzzle, including the equilibrium pricing hypothesis, differential demand/supply hypothesis, liquidity hypothesis, and information asymmetry hypothesis.

The differential demand/supply hypothesis explains the differential prices of unrestricted and restricted claims of the same underlying equity using the distinctive demand and supply conditions in segmented markets. Fernald and Rogers (2002) and Chan and Kwok (2005) argue that observed A-share premiums largely reflect the relative supply shortage of restrictive A-shares, especially in Chinese markets where domestic investors have limited alternative investment opportunities. Broadly consistent with the argument of differential demand for China's dual-listed stocks, Sun and Tong (2000) find that B-shares discounts are larger when good substitute equities for B-shares are available to foreign investors in the Hong Kong stock market. More recently, Mei et al. (2009) present evidence of excessively speculative trading behaviour among Chinese domestic investors and find correlation between the cross-section variations in the degree of speculativeness of restricted shares and the price differences in dual-listed stocks.

The liquidity hypothesis pins the price discounts in dual-listed stocks on the relative illiquidity of B-shares. Chen et al. (2001) and Chen and Xiong (2001) argue that relatively illiquid $\mathrm{B}$-shares command price discounts that are necessary to compensate for investors' preference for liquidity. They find empirical evidence that B-share price discounts decrease with overall firm sizes, a proxy for liquidity.

The information asymmetry hypothesis states that domestic investors are better informed than foreign investors and therefore foreign investors require higher expected returns and therefore result in a lower price for B-shares (see e.g. Chakravarty et al., 1998; Kutan and Zhou, 2006; Zhou et al., 2006). However, there exists mixed empirical evidence on the information advantage of Chinese domestic investors. Chui and Kwok (1998) find that information flows from the B- to the A-share market and the results were 
confirmed by Sjoo and Zhang (2000). On the contrary, using a unique database of intraday transactions data, Chan et al. (2007) reveal the dominant role of the A-shares in price discovery over time.

Following the equilibrium pricing approach, we examine whether differential risk exposures to contimions and jump factors in A- and B-share markets explain the lower prices of B-shares. Canonical CAPM suggests that expected returns, and therefore security prices, are determined by systematic risks - stocks with higher systematic risk require higher risk premiums. Price differentials between dual-listed stocks paying the same dividends exist as long as risk exposures are different in segmented markets. Notably two studies have used the approach to explain price differences in segmented markets. For a partially-segmented stock market, Hietala (1989) shows that restricted shares (e.g. A-shares held by domestic investors) trade at a premium if foreign investors require a higher risk premium (therefore a lower price) on unrestricted shares (e.g. B shares) than domestic investors. Assuming negative risk-aversion coefficient (riskloving) for domestic investors, Ma (1996) finds that different systematic risks explain the cross-sectional variation of B-share discounts, although he did not separately model continuous and jump systematic risk.

To our best knowledge, this is the first study of the B-share discount puzzle that emphasises differential exposures of dual-listed stocks to market risks and the decomposition of the total systematic risk into continuous risk and jump risk. The jumpdiffusion model assumes that random changes in the risk factor come from two sources. The first source describes the typical market movements (continuous component) and the second source describes crisis movements (jump component). In a simplified form, there is a probability of $P$ that the sample will come from the continuous distribution and a small probability of $(1-P)$ that it will come from the crisis distribution (Andersen et al., 2003; Dunham and Friesen, 2007; Zhou and Zhu, 2012b). Accounting for jump risks is essential in evaluating risk exposures in Chinese emerging stock markets, where large and sudden changes in stock prices and volatility are more often observed as a result of major market events or policy changes (Colwell et al., 2007; Zhou and $\mathrm{Zhu}, 2012 \mathrm{a}$ ). We find some evidence that jump risks, along with continuous risks, are important in explaining cross-sectional variations in B-share discounts.

The study proceeds as follows. Section 2 describes an equilibrium asset pricing model, derives its empirical implications, and outlines the methodologies that estimate risk exposures to the systematic continuous and jump risk. Data and sampling procedures are described in Section 3. Section 4 presents the empirical findings and Section 5 offers concluding remarks.

\section{Methodology}

\subsection{An equilibrium asset pricing model for dual-listed stocks}

In our equilibrium pricing model, the domestic and foreign investors are allowed to require different risk premiums on $\mathrm{A}$ - and $\mathrm{B}$-shares with identical dividends, which can be caused by limited investment opportunities for domestic investors, illiquid B-shares, or asymmetric information between domestic and global investors. Based on CAPM, the risk premiums on $\mathrm{A}$ - and $\mathrm{B}$-shares are:

$$
E\left(R_{J, i}\right)-R_{f}=\beta_{J, i}\left[E\left(R_{J, m}\right)-R_{f}\right]=\beta_{J, i} \lambda_{J, m}, J=A, B .
$$


We further denote $\lambda_{J}=E\left(R_{f, m}\right)-R_{f}$ as the expected market risk premium of the domestic (or global) equity market.

We assume a common risk-free rate for both domestic and foreign investors. Though the segmentation of China's stock market prohibits foreign investors from investing in the A-share equity market, foreign investors have literally no restrictions on earning the risk-free rate in China from investing in assets such as deposit savings. Moreover, for those foreign investors who participate in trading B-shares, the flow of their foreign currency denominated funds are strictly regulated and tend to stay in China to earn local rate of return on risk-free asset other than a global risk-free rate. We later relax this assumption to allow global investors earning global risk-free rates and obtain similar results.

Based on the perpetual constant dividend discount model, higher required rates of return lead to lower stock prices, given that A- and B-shares carry the same amount of dividend. If $B$-share investors require a higher retum, they are willing to pay a lower price for the same amount of dividends that A-share investors receive, therefore resulting in B-share discounts.

The formation of the price for A- and B-share of dual-listed stock $i$ follows:

$$
P_{A, i}=\frac{D}{R_{f}+\beta_{A, i} \lambda_{A}}+\varepsilon_{A, i}, \quad P_{B, i}=\frac{D}{R_{f}+\beta_{B, i} \lambda_{B}}+\varepsilon_{B, t},
$$

where $\varepsilon_{A}$ and $\varepsilon_{B}$ are the stochastic components that jointly determine the market prices of $A$ - and B-shares for firm $i$. Mei et al. (2009) argued that $\varepsilon_{A}$ and $\varepsilon_{B}$ represent persistent speculative shocks to the markets; and the difference in the mean level of $\varepsilon_{A}$ and $\varepsilon_{B}$ alone may explain the price differential between two markets. We however focus on an explanation of the same phenomena based on an equilibrium asset pricing model that always assumes the stochastic term to be zero mean. ${ }^{2}$ Thus, the B-share discount for firm $i$ can be expressed as:

$$
\rho_{i}=\frac{P_{B, i}-P_{A, i}}{P_{A, i}}=\frac{\beta_{B, i} \lambda_{B}-\beta_{A, i} \lambda_{A}}{R_{f}+\beta_{A, i} \lambda_{A}} .
$$

Given market prices of systematic risk $\lambda_{A}$ and $\lambda_{B}$, B-share discount increases with $\beta_{A, i}$ decreases with $\beta_{B, i}$, and increases with the disparity between $\beta_{A, i}$ and $\beta_{B, i}$.

\subsection{Regression models}

In this study, two groups of regression models are used:

$$
\begin{aligned}
& \text { DISCOUNT } i t=\alpha+\gamma_{d} \beta_{A_{i t} i}+\gamma_{B} \beta_{B_{i t} i t}+\gamma^{\prime} X_{t t}+\varepsilon_{i t}, \\
& \text { DISCOUNT } i t=\alpha+\gamma_{A}^{C} \beta_{A, t t}^{\text {Cont }}+\gamma_{B}^{C} \beta_{B, t t}^{\text {Cont }}+\gamma_{A}^{J} \beta_{A, i t}^{\text {Jump }}+\gamma_{B}^{J} \beta_{B, i t}^{J u m p}+\gamma^{\prime} X_{u}+\varepsilon_{l t} .
\end{aligned}
$$

We include the systematic risks in both $\mathrm{A}$ - and B-share markets in the first model. Additionally, we decompose risks into continuous and jump risks and include them in the second model to test the differential effects of jump risks to B-share discounts. DISCOUNT is the monthly average of daily-price discounts defined as: $\left(P_{B, f}-P_{A, t}\right) / P_{A, t}$, 
where $P_{A, i}$ and $P_{B, i}$ are daily prices for A- and B-shares expressed in US dollars, respectively. $X$ are the chosen explanatory variables to test different explanations of $B-$ share discount. Total betas $\left(\beta_{A}\right.$ and $\left.\beta_{B}\right)$ are estimated from regressing daily stock returns on the relevant market index returns (see Section 2.3 for details). MSCI China A-share Index is used as a proxy for A-share market index while MSCI World Index is used a proxy for $\mathrm{B}$-share market index. Continuous $\left(\beta_{A, i}^{\text {Com. }}\right.$ and $\left.\beta_{B, i}^{\text {Cont }}\right)$ and jump betas $\left(\beta_{A, i}^{\text {Junp }}\right.$ and $\beta_{B, i}^{\text {Jump }}$ ) are estimated using Dunham and Friesen's (2007) method (see Section 2.5 for details).

In an asset pricing model of partially segmented markets, Hietala (1989) argues that price discounts can be caused by different rates of return required by distinct groups of investors and that magnitudes of discounts are determined by different betas in segmented markets. Hietala documents that beta differences explain price differences exist in the Finn ish market. Following the study of Hietala (1989), we use the base model specified in equations (4) and (5) to test the equilibrium pricing hypothesis that B-share discounts are related to differential betas in A- and B-shares.

The B-share market has relatively small market capitalisation and many stocks are very illiquid. Therefore, it may be difficult for large foreign institutional investors to adjust their portfolios quickly without causing sudden movement in stock prices. Following the study of Bailey and Jagtiani (1994), Hietala (1989) and Yang and Lau (2005), we add a LIQUID variable, defined as the ratio of daily trading volume of the $\mathrm{B}$-share to that of the A-share, to test the liquidity hypothesis that the illiquidity in Bshares is negatively correlated with B-share price discount.

Due to differences in culture, accounting standards, disclosure requirements, and regulatory environments across countries, it is more difficult for foreign investors to acquire the same information on Chinese firms than domestic investors do (Kang and Stulz, 1997). Therefore, foreign investors may require a higher return on B-shares, resulting in B-share discount. We use firm size, defined as the monthly average of the daily sum of the market values of tradable A- and B-shares in billions of US dollars, as a proxy for information asymmetry (Sun and Tong, 2000; Yang and Lau, 2005). SIZE is added to the base models in equations (4) and (5) to test the information asymmetry hypothesis.

As Bailey (1994) argued that there are fewer investment alternatives available to domestic Chinese investors compared to investors in B-shares, resulting in lower demand elasticity for A-shares. SUPPLY, the ratio of number of outstanding B-shares to that of outstanding A-shares, is included in equation (4) and (5) to test the differential demand hypothesis.

\subsection{Beta estimation}

Following the study of Hietala (1989), two sets of betas are estimated for the 86 crosslisted stocks in both the A- and B-share markets.

$1 \beta_{A} \mathrm{~s}$, both rolling and non-rolling, are estimated from a market model using daily returns:

$$
R_{A, i, s}=\alpha_{A, i}+\beta_{A, i} R_{A, i}+\varepsilon_{A, i, t},
$$


where $R_{A, i, r}$ is the return on stock $i$ 's A-share on day $t, \lambda_{A, i}$ is the A-share alpha for stock $i, \beta_{A, i}$ is the A-share beta for stock $i, R_{A, t}$ is the return of the Chinese market portfolio on day $t . R_{A, r}$ is estimated by the return on the dividend adjusted MSCI China A Index, a value-weighted index includes A-share securities listed on both Shanghai and Shenzhen Stock Exchanges.

$2 \beta_{B}$ s, both rolling and non-rolling, are estimated from the market model using daily returns:

$$
R_{B, i, t}=\alpha_{B, i}+\beta_{B, i} R_{B, r}+\varepsilon_{B, i, r}
$$

where $R_{B, i, i}$ is the return on stock $i$ s B-share on day $t, \alpha_{B, i}$ is the B-share alpha for stock $i$, $\beta_{B, i,}$ is the B-share beta for stock $i, R_{B, i}$ is the dividend adjusted MSCI ACWI (All Country World Index) Index; a value-weighted index that is designed to measure the equity market performance of developed and emerging markets consisting of 48 country indices comprising 23 developed and 25 emerging market country indices.

\subsection{Estimation of jump risk}

Following the work of Barndorff-Nielsen and Shephard $(2004,2006)$, we define the jump component of the realised volatility on day $t$ :

$$
J_{t, \alpha}^{*}=I\left[Z J_{t}^{*}>\Phi_{a}\right] \cdot\left(R V_{t}^{*}-B V_{t}^{*}\right)
$$

where

$$
Z J_{t}^{*}=\frac{R J_{t}^{*}}{\sqrt{(1 / m) \times\left[(\pi / 2)^{2}+\pi-5\right] \times \max \left(1, T P_{t}^{*} / B V_{t}^{* 2}\right)}} \rightarrow N(0,1) .
$$

We use the staggered realised bipower variation and staggered realised tripower quarticity to correct for potential market microstructure noises:

$$
B V_{i+1}^{*}(\Delta) \equiv \mu_{1}^{-2} \times \frac{m}{m-2} \times \sum_{j=2}^{1 / \Delta}\left|r_{t+j \Delta, \Delta} \| r_{t+(j-2) \Delta, \Delta}\right|,
$$

and

$$
T P_{\ell}^{*} \equiv \mu_{4 / 3}^{-3} \times m \times \frac{m}{m-4} \times \sum_{j=3}^{m}\left|r_{t,(j-4) \Delta}\right|^{4 / 3}\left|r_{t,(j-2) \Delta}\right|^{4 / 3}\left|r_{t, j \Delta}\right|^{4 / 3}
$$

where $m$ is the number of high-frequency intervals during a trading day.

The continuous sample path variation is estimated as:

$$
C_{t, \alpha}^{*}=I\left[Z J_{t}^{*} \leq \Phi_{\alpha}\right] \cdot R V_{t}+I\left[Z J_{t}^{*}>\Phi_{\alpha}\right] \cdot B V_{t}^{*} \text {, }
$$

such that equations (8) and (12) sum to the total realised volatility on any given trading day. As long as $\Phi_{\alpha}>0$, equations (8) and (12) ensures that $J_{t, \alpha}$ and $C_{t, \alpha}$ are both nonnegative. All empirical results reported in the remaining sections are based on $\alpha=.001$. As robustness tests, we also examine the empirical results based on $\alpha=.005$ and .01 . The results are quantitatively similar to those reported in this study. 


\subsection{Decomposition of betas}

We follow the two-step procedure proposed by Dunham and Friesen (2007) to estimate the systematic and non-systematic jump risks for each individual stock. First, the systematic risk is decomposed into continuous and jump risks by regressing total returns on market continuous returns and market jump returns: ${ }^{3}$

$$
R_{i j}=\alpha_{i}+\beta_{i i}\left(R_{M t}-J_{M i t}^{\text {jump }}\right)+\beta_{2 i} J_{M t}^{j \mathrm{kump}}+\eta_{i t}
$$

where $R_{i t}$ and $R_{M t}$ denote daily returns of individual stock $i$ and market portfolio $M$, respectively. $J_{t, a}^{\text {jump }}=\operatorname{sign}\left(R_{t}\right) \sqrt{\tilde{J}_{t} \times I\left[Z J_{t}>\Phi_{a}\right]}$ with $\operatorname{sign}\left(R_{t}\right)$ equals to 1 if $R_{t}$ is positive and -1 if $R_{t}$ is negative. $\tilde{J}_{t}$ is the jump component in the realised volatility defined in equation (8) and $I\left[Z J_{1}>\Phi_{\alpha}\right]=1$ if $Z J_{1}>\Phi_{\alpha}$ and equals to 0 otherwise. $J_{M t}^{j u m p}$ and $J_{i t}^{j u m p}$ are jump returns of the market portfolio $M$ and individual stock $i$, respectively.

We further decompose the idiosyncratic component $\eta_{i t}$ into non-systematic jump risk $\hat{\kappa}_{i t}$ and idiosyncratic continuous risk $\varepsilon_{i j}$ :

$$
\begin{aligned}
& \hat{\kappa}_{i t}=J_{i t}^{j u m p}-\hat{\beta}_{2 i} J_{M t}^{j u m p}, \text { and } \\
& \hat{\varepsilon}_{i t}=R_{i t}-\left[\hat{\alpha}_{t}+\hat{\beta}_{1 t}\left(R_{M t}-J_{M t}^{j u m p}\right)+\hat{\beta}_{2 t} J_{M t}^{j \text { junp }}+\hat{\kappa}_{i t}\right] .
\end{aligned}
$$

Therefore, any asset returns, $R_{i}$, can be decomposed into four different components:

$$
R_{i t}=\alpha_{i}+\beta_{i i}\left(R_{i j t}-J_{i M t}^{j u m p}\right)+\beta_{2 i} J_{i t t}^{j u m p}+K_{i t}+\varepsilon_{i t}
$$

In equation (16), the total return of stock $i$ consists of four components: systematic/ market continuous return, $\beta_{1 i}\left(R_{M t}-J_{M t}^{\text {jump }}\right)$; systematic/market jump return, $\beta_{2 t} J_{M L}^{\text {jump }}$; non-systematic/idiosyncratic jump return, $\kappa_{i t}=J_{i t}^{\text {jump }}-\beta_{2 i} J_{M t}^{\text {jump }}$; and non-systematic/ idiosyncratic continuous return, $\varepsilon_{i t}$.

\section{Data and sample}

The sample includes 86 cross-listed stocks in both A- and B-shares, 44 of which are listed at the Shanghai Stock Exchange and 42 at the Shenzhen Stock Exchange. Fiveminute and daily-price data between January 2004 and December 2007 are retrieved from the analyst and CSMAR.

Unlike the NYSE, the trading hours of the Shanghai Stock Exchange span two sessions on any trading days, from 9:30 AM to 11:30 AM and from 1:00 PM to 3:00 PM with a short lunch break in between. The data vendor follows the previous tick method to take the first observation during a five-minute interval as the sample price. Hansen and Lunde (2006) showed that the previous tick method is a sensible way to sample prices in calendar time. Therefore, the first five-minute price of a day is the first valid trading price between 9:30:01 $\mathrm{AM}$ and 9:35:00 $\mathrm{AM}$, and the last five-minute price in the morning 
session is the first valid trading price between 11:25:01 AM and 11:30:00 AM. The first price observed on the afternoon session is the first valid trading price from $1: 30: 01 \mathrm{PM}$ to 1:35:00 PM and the last price is the first valid trading price from 2:55:01 PM to 3:00:00 PM. At most we have 48 observations of five-minute returns in a normal trading day, provided there is at least one transaction in record in every five-minute interval. We treat returns over non-trading intervals as missing values and exclude them from the data set.

Following Dunham and Friesen's (2007) study, we implement the sandwich filter method to eliminate quotations that are $10 \%$ or further away in absolute value of the surrounding prices. Visual investigation of the quotes reveals that there are a large number of erroneous quotes for 6 January 2004 when the data first became available, for 30 December 2006, for 16 January 2007, and for November 2006. Observations in these sample periods are therefore excluded from this study. We also eliminate the first 22 trading days (approximately one month) for each stock when it first appears in the data set, so that our test results are less likely to be driven by the irregular and extreme price movements in days immediately after initial public offerings.

\section{Empirical results}

\subsection{Summary statistics}

Table 1 reports summary statistics for different regression variables, including total, continuous and jump rolling betas, as well as B-share price discounts. Table 1 shows that, on average, the beta for A-shares is 0.2352 and for $B$-shares is 0.5264 . Similar results are observed in continuous betas. Average jump betas are 1.3906 and 1.4257 for A- and Bshares, respectively. The higher jump betas indicate that the dual-listed stocks are more responsive to market-wide crisis information than to non-crisis events.

$\mathrm{B}$-share discount is the monthly average daily-price discount defined as $\left(P_{B}-P_{A}\right) / P_{A}$, where $P_{A}$ and $P_{B}$ are daily prices for A- and B-shares expressed in US dollars, respectively. The results show that B-share discount persists after China opened its Bshare market to domestic residents, ranging from a discount of $37-48 \%$. The magnitudes of the discounts are comparable to those reported in the work of Chan et al. (2008), Sun and Tong (2000) and Yang and Lau (2005) in 1990s. Table 2 also documents the continuing growth of China's foreign exchange reserve, with an average increase of 250 million US dollars per month.

\subsection{Testing different hypotheses of B-share discounts}

Columns (1)-(5) in Table 2 report the regression results for total betas, $\beta_{A}$ for A-shares and $\beta_{B}$ for $\mathrm{B}$-shares, which are estimated from regressing stock returns on the relevant market index retums. MSCI China A-Share Index is used as a proxy for the A-share market index, while MSCI World Index is used a proxy for the B-share market index. The basic model shows that the systematic risk of A-shares, $\beta_{A}$, is positively correlated with the B-share discount, implying an increase in A-share risk shrinks B-share discount. Intuitively it means that the higher risk in A-shares will lead to a lower price asked by the Chinese domestic investors, consequently resulting in a lower B-share discount. 
Monthly summary statistics of regression variables are presented. Except for CFOREX, the cross-sectional monthly averages of all sample firms over different years are reported Betas are estinated me Index is used as a ( $\beta_{A}^{\text {hemp }}$ and $\beta_{a}^{\text {hany }}$ ) are estimated using Dunhama and Friesen (2007) method. SIZE is the sum of market value of tradable A- and B-shares in billion US dollars. SUPPLY is the ratio of number of outstanding B-shares to that of outstanding A-shares. DISCOUNT is monthly average daily-price discount defined as $\left(P_{B 3}-P_{A}\right) / P_{A}$, where $P_{A}$ and $P_{B}$ are daily prices for A- and B-shares expressed in US dollars, respectively. LIQUID is the ratio of trading volume in US dollars for B-shares to that for A-shares. CFOREX is the monthly change in China's foreign exchange reserves and is in millions of US dollars

\begin{tabular}{|c|c|c|c|c|c|c|c|c|c|c|c|}
\hline Year & $\beta_{A}$ & $\beta_{B}$ & $\beta_{t}^{C \text { Cordments }}$ & 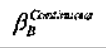 & $\beta_{A}^{\text {hamp }}$ & $\beta_{A}^{\text {hump }}$ & $S I Z E$ & SUPPLY & DISCOUNT & LQUDD & CFOREX \\
\hline 2004 & 0.0555 & 0.1159 & 0.0556 & 0.1198 & 0.6670 & 1.1237 & 0.0635 & 0.4519 & -0.4812 & 0.5661 & 173.6292 \\
\hline 2005 & 0.1620 & 0.5652 & 0.1492 & 0.5695 & 1.7587 & 1.3693 & 0.0507 & 0.5486 & -0.4780 & 0.4200 & 403.4014 \\
\hline 2006 & 0.3060 & 0.5605 & 0.2993 & 0.5483 & 1.4391 & 1.5568 & 0.0770 & 0.5381 & -0.3677 & 0.3387 & 176.3975 \\
\hline 2007 & 0.1834 & 0.7443 & 0.1801 & 0.7471 & 0.3702 & 0.8675 & 0.1122 & 0.5741 & -0.4065 & 16.6472 & 416.5202 \\
\hline Mean & 0.2352 & 0.5264 & 0.2278 & 0.5211 & 1.3906 & 1.4257 & 0.0704 & 0.5341 & -0.4110 & 1.2470 & 250.1448 \\
\hline
\end{tabular}




\begin{tabular}{|c|c|c|c|c|c|c|c|c|c|c|c|}
\hline \multicolumn{12}{|c|}{$\begin{array}{l}\text { The regression results of simple multivariate cross- } \\
\text { DISCOUNT } T_{i}=\alpha+\gamma_{A} \beta_{A, i}+\gamma_{B} \beta_{B, t}+\gamma^{\prime} X_{i}+\varepsilon_{i}\end{array}$} \\
\hline \multicolumn{12}{|c|}{ 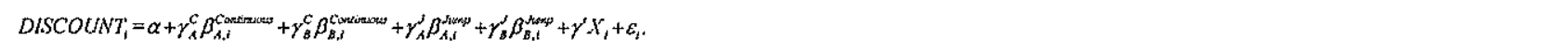 } \\
\hline \multirow{2}{*}{\multicolumn{12}{|c|}{ 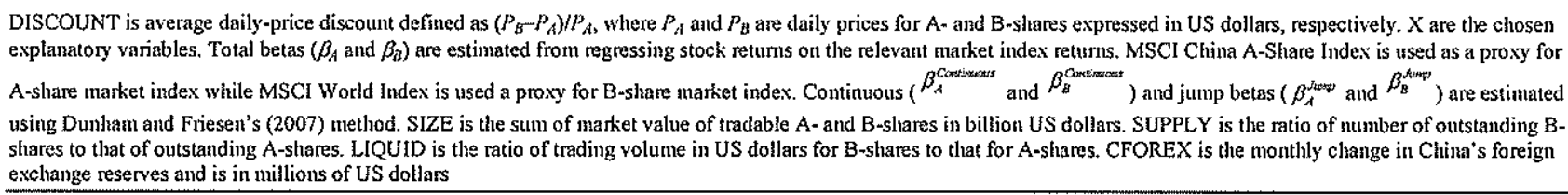 }} \\
\hline & & & & & & & & & & & \\
\hline & (I) & (2) & (3) & 14 & (5) & & (6) & (7) & (8) & (9) & (10) \\
\hline \multirow{2}{*}{$\beta_{i}$} & $\begin{array}{l}0.7342^{* * * *} \\
(0.1727)\end{array}$ & $\begin{array}{l}0.7084^{* *} \\
(0.1728)\end{array}$ & $\begin{array}{l}0.4507^{* *} \\
(0.1744)\end{array}$ & $\begin{array}{l}0.7515 * * \\
(0.1744)\end{array}$ & $\begin{array}{l}0.436 * * \\
(0.1718)\end{array}$ & $\beta_{A}^{\text {Cartimatexs }}$ & $\begin{array}{l}0.6831^{* *} \\
(0.1757)\end{array}$ & $\begin{array}{c}0.6687 * * * \\
(0.1758)\end{array}$ & $\begin{array}{l}0.3928^{* *} \\
(0.177)\end{array}$ & $\begin{array}{l}0.7104^{\mathrm{kt}} \\
(0.1768)\end{array}$ & $\begin{array}{l}0.3962^{* *} \\
(0.1733)\end{array}$ \\
\hline & & & & & & $\beta_{A}^{\text {sumpor }}$ & $\begin{array}{c}0.0342 \\
(0.0213)\end{array}$ & $\begin{array}{c}0.0298 \\
(0.0216)\end{array}$ & $\begin{array}{l}0.0342^{*} \\
(0.0196)\end{array}$ & $\begin{array}{l}0.0373^{*} \\
(0.0215)\end{array}$ & $\begin{array}{l}0.0363^{*} \\
(0.0197)\end{array}$ \\
\hline \multirow{2}{*}{$\beta_{B}$} & $\begin{array}{l}-0.06 \\
(0.0497)\end{array}$ & $\begin{array}{r}-0.0622 \\
(0.0495)\end{array}$ & $\begin{array}{l}-0.0571 \\
(0.0458)\end{array}$ & $\begin{array}{l}-0.0653 \\
(0.0502)\end{array}$ & $\begin{array}{l}-0.0694 \\
(0.0453)\end{array}$ & $\beta_{B}^{\text {cantineness }}$ & $\begin{array}{l}-0.0564 \\
(0.0556)\end{array}$ & $\begin{array}{l}-0.0581 \\
(0.0555)\end{array}$ & $\begin{array}{l}-0.0601 \\
(0.0511)\end{array}$ & $\begin{array}{l}-0.0546 \\
(0.0555)\end{array}$ & $\begin{array}{r}-0.0588 \\
(0.0499)\end{array}$ \\
\hline & & & & & & $\beta_{B}^{\text {sumprop }}$ & $\begin{array}{l}-0.0108 \\
(0.0158)\end{array}$ & $\begin{array}{r}-0.0099 \\
(0.0158)\end{array}$ & $\begin{array}{l}-0.006 \\
(0.0146)\end{array}$ & $\begin{array}{c}-0.018 \\
(0.0169)\end{array}$ & $\begin{array}{l}-0.0169 \\
(0.0153)\end{array}$ \\
\hline LIQUID & & $\begin{array}{l}-0.028 \\
(0.002)\end{array}$ & & & $\begin{array}{l}-0.0024 \\
(0.0019)\end{array}$ & LIQUID & & $\begin{array}{l}-0.0024 \\
(0.0021)\end{array}$ & & & $\begin{array}{l}-0.0018 \\
(0.0019)\end{array}$ \\
\hline SIZE & & & $\begin{array}{l}0.4247^{* *} \\
(0.1069)\end{array}$ & & $\begin{array}{c}0.4664^{* * *} \\
(0.1078)\end{array}$ & SIZE & & $(0.1068)$ & $0.4266^{* *}$ & $(0.107)$ & $0.4732^{* *}$ \\
\hline SUPPLY & & & & $\begin{array}{l}-0.0232 \\
(0.0281)\end{array}$ & $\begin{array}{c}-0.0465^{*} \\
(0.0262)\end{array}$ & SUPPLY & & & & $\begin{array}{l}-0.0349 \\
(0.0301)\end{array}$ & $\begin{array}{c}-0.0588^{* *} \\
(0.0279)\end{array}$ \\
\hline
\end{tabular}


Bailey and Jagtiani (1994) find a positive correlation between liquidity and the foreign share premium in Thailand; and Yang and Lau (2005) find that liquidity is positively correlated with B-share discount in China. Therefore, we include LIQUID, the ratio of trading volume in US dollar for B-shares to that for A-shares, in Column (2) in Table 2, to test the liquidity hypothesis. Results show that after controlling for the liquidity effect, systematic risk of A-shares is still an important pricing factor.

SIZE is included in Model 3 to test the information asymmetry hypothesis. Results show that SIZE is positively corrected with B-share discount, implying that large firms have a smaller degree of information asymmetry and therefore have a smaller size of B-share discount. However, after controlling for SIZE information asymmetry, the systematic risk is still positively correlated with B-share discount.

Model 4 tests the differential demand hypothesis, together with the equilibrium pricing hypothesis. Results show that the demand curve for B-shares is not downward sloping. In Model 5, four different hypotheses are tested together with equilibrium pricing hypothesis. The results are very similar to those in Models 1-5, except for a marginally significant SUPPLY effect.

In summary, there is a significantly positive correlation between A-share systematic risk and B-share discount. At the same time, information asymmetry effect is also observed over the sample period.

Recently, researchers have documented the importance of modelling both continuous and discrete components of systematic risks (see e.g. Dunham and Friesen, 2007). This study decomposes the total betas into continuous and jump betas and then examine their impact on B-share discounts. The results, reported in Panel II of Table 3, show that Ashare continuous betas have dominating effect in all five models, although their magnitudes are slightly smaller than those reported in Panel I of Table 3. More importantly, Table 3 presents some evidence that jump risk factor is a pricing factor. In Models $3-5$, the coefficients of A-share jump beta, $\beta_{A}^{\text {Jump }}$, are significantly positive at $5 \%$, implying a positive correlation between B-share discount and A-share systematic jump risk. The results illustrate the importance of modelling both components of systematic risks.

In summary, there exists strong evidence that B-share discount is caused by different rates of return required by segmented investors: Chinese domestic investors for A-shares and global investors for B-shares. Due to the restrictions placed by Chinese government on the financial assets that Chinese domestic investors can choose and the restrictions on the financial assets that global investors can invest inside China, the two groups of investors are faced different diversification risk, resulting in different levels of required return. The different required returns result in different levels of pricing on A- and B-shares listed by the same company.

\subsection{Robustness tests}

\subsubsection{Cross-sectional analysis for separate samples}

Cross-sectional analysis results on separate samples for cross-listed firms at Shanghai and Shenzhen market are reported in Table 3. Consistent with findings in Panel 1 of Table 3, strong evidence exists that A-share systematic risk is positively correlated with B-share discount. The results are stronger in Shenzhen market than in Shanghai market. Also consistent with results in Panel II of Table 3, some evidence exists that both continuous and jump betas are important in pricing cross-listed stocks. 
The regression results of simple muttivariate cross-sectional regression models in the following two forms are reported:

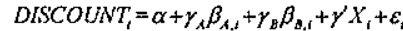

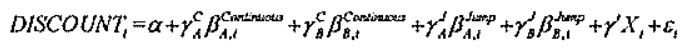

DISCOUNT is average daily-price discount defined as $\left(P_{B}-P_{A}\right) / P_{A}$, where $P_{A}$ and $P_{B}$ are daily prices for A- and B-shares expressed in US dollars, respectively. $\mathrm{X}$ are the chosen explanatory variables. Total betas $\left(\beta_{A}\right.$ and $\beta_{2}$ ) are estimated from regressing stock returns on the relevant market index returns. MSCI Clina $\mathrm{A}-S$ hare findex is used as a proxy for

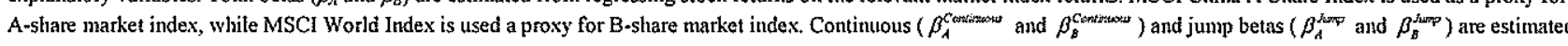
using Dunham and Friesen's (2007) method. SIZE is the sum of market value of tradable A- and B-shares in billion US dollars. SUPPLY is the ratio of number of outstanding Bshares to that of outstanding A-shares. LIQUID is the ratio of trading volume in US dollars for B-shares to that for A-shares. CFOREX is the monthly change in China's foreign exchange reserves and is in millions of US dollars.

\begin{tabular}{|c|c|c|c|c|c|c|c|c|c|c|}
\hline & \multicolumn{2}{|c|}{ (l) } & \multicolumn{2}{|c|}{ (2) } & \multicolumn{2}{|c|}{ (3) } & \multicolumn{2}{|c|}{ (4) } & \multicolumn{2}{|c|}{ (5) } \\
\hline & $S H$ & $S Z$ & $S H$ & $S Z$ & SH & $S Z$ & $S H$ & $S Z$ & $S H$ & $S Z$ \\
\hline \multicolumn{11}{|c|}{ Panel I: Regression Analysis of Total Betas } \\
\hline$\beta_{A}$ & $\begin{array}{c}0.06858 * * \\
(0.2887)\end{array}$ & $\begin{array}{c}0.7727 * * * \\
(0.2109)\end{array}$ & $\begin{array}{c}0.4459 \\
(0.2716)\end{array}$ & $\begin{array}{c}0.7321 * * * * \\
(0.2101)\end{array}$ & $\begin{array}{c}0.4401 \\
(0.3013)\end{array}$ & $\begin{array}{l}0.4024^{*} \\
(0.2012)\end{array}$ & $\begin{array}{l}0.582^{* *} \\
(0.2419)\end{array}$ & $\begin{array}{c}0.7997 * * * \\
(0.2161)\end{array}$ & $\begin{array}{c}0.4164 \\
(0.2725)\end{array}$ & $\begin{array}{l}0.3985^{*} \\
(0.1993)\end{array}$ \\
\hline$\beta_{B}$ & $\begin{array}{l}-0.0287 \\
(0.0669)\end{array}$ & $\begin{array}{c}-0.1151 \\
(0.0804)\end{array}$ & $\begin{array}{l}-0.0072 \\
(0.0609)\end{array}$ & $\begin{array}{l}-0.121 \\
(0.0794)\end{array}$ & $\begin{array}{c}-0.047 \\
(0.0649)\end{array}$ & $\begin{array}{l}-0.1077 \\
(0.0682)\end{array}$ & $\begin{array}{r}-0.0051 \\
(0.0561)\end{array}$ & $\begin{array}{l}-0.124 \\
(0.082)\end{array}$ & $\begin{array}{l}-0.0208 \\
(0.0558)\end{array}$ & $\begin{array}{l}-0.153^{*} \\
(0.0675)\end{array}$ \\
\hline LIQUID & & & $\begin{array}{c}-0.1214^{* * * *} \\
(0.0381)\end{array}$ & $\begin{array}{c}-0.027 \\
(0.0019)\end{array}$ & & & & & $\begin{array}{c}0.0103 \\
(0.0611)\end{array}$ & $\begin{array}{l}-0.0025 \\
(0.0016)\end{array}$ \\
\hline SIZE & & & & & $\begin{array}{l}0.8354^{* * *} \\
(0.3992)\end{array}$ & $\begin{array}{c}0.4048^{* * *} \\
(0.1006)\end{array}$ & & & $\begin{array}{l}0.6336^{*} \\
(0.3439)\end{array}$ & $\begin{array}{c}0.4096^{* * *} \\
(0.0986)\end{array}$ \\
\hline SUPPLY & & & & & & & $\begin{array}{c}-0.5376^{* * *} \\
(0.1235)\end{array}$ & $\begin{array}{l}-0.0257 \\
(0.038)\end{array}$ & $\begin{array}{c}-0.5358^{* *} \\
(0.2162)\end{array}$ & $\begin{array}{c}-0.036 \\
(0.0314)\end{array}$ \\
\hline
\end{tabular}


The regression restlts of simple mttltivariate cross-sectional regression models in the following two forms are reported:

DISCOUNT $T_{1}=\alpha+\gamma_{1} \beta_{A_{1}}+\gamma_{B} \beta_{0+1}+\gamma^{\prime} X_{2}+\varepsilon_{1}$

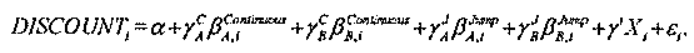

DISCOUNT is average daily-price discount defined as $\left(P_{B}-P_{A}\right) / P_{A}$, where $P_{A}$ and $P_{B}$ are daily prices for $\mathrm{A}$ - and $\mathrm{B}$-shares expressed in US dollars, respectively. $\mathrm{X}$ are the closen explanatory variables. Total betas $\left(\beta_{A}\right.$ and $\beta_{B}$ ) are estimated from regressing stock returns on the relevant market index returns. MSCI China A-Share index is used as a proxy for

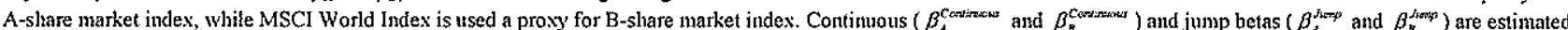
using Dunham and Friesen's (2007) method. SIZE is the sum of market value of tradable A- and B-slares in billion US dollars. SUPPLY is the ratio of number of outstanding Bshares to that of ontstanding A-shares. LIQUID is the ratio of trading volune in US dollars for B-shares to that for A-slares. CFOREX is the monthly change in Clina's foreign exchange reserves and is in:

\begin{tabular}{|c|c|c|c|c|c|c|c|c|c|c|}
\hline & \multicolumn{2}{|c|}{ (6) } & \multicolumn{2}{|c|}{ (7) } & \multicolumn{2}{|c|}{ (8) } & \multicolumn{2}{|c|}{ (9) } & \multicolumn{2}{|c|}{ (10) } \\
\hline & SH & $S Z$ & $S H$ & $S Z$ & SH & $S Z$ & $\mathrm{SH}$ & $s z$ & SH & $S Z$ \\
\hline \multicolumn{11}{|c|}{ Pane IJ: Regression Analysis of Decomposed Betas } \\
\hline 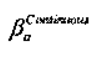 & $\begin{array}{c}0.6007^{* *} \\
(0.2858)\end{array}$ & $\begin{array}{r}0.8042^{* * *} \\
(0.2187)\end{array}$ & $\begin{array}{l}0.4167 \\
(0.2705)\end{array}$ & $\begin{array}{c}0.7752^{* * *} \\
(0.2121)\end{array}$ & $\begin{array}{c}0.397 \\
(0.3084)\end{array}$ & $\begin{array}{l}0.3952^{*} \\
(0.2152)\end{array}$ & $\begin{array}{c}0.5236 * * \\
(0.2391)\end{array}$ & $\begin{array}{c}0.8318^{* * *} \\
(0.2236)\end{array}$ & $\begin{array}{c}0.4247 \\
(0.2752)\end{array}$ & $\begin{array}{l}0.4276^{*} \\
(0.2119)\end{array}$ \\
\hline$\beta_{a}^{h m p}$ & $\begin{array}{r}0.0686^{* *} \\
(0.0289)\end{array}$ & $\begin{array}{r}-0.0291 \\
(0.035)\end{array}$ & $\begin{array}{r}0.0537^{*} \\
(0.027)\end{array}$ & $\begin{array}{r}-0.0522 \\
(0,036)\end{array}$ & $\begin{array}{l}0.0555^{*} \\
(0.0295)\end{array}$ & $\begin{array}{l}0.0027 \\
(0.0311)\end{array}$ & $\begin{array}{l}0.0568^{* *} \\
(0.0242)\end{array}$ & $\begin{array}{l}-0.0295 \\
(0.0353)\end{array}$ & $\begin{array}{l}0.0504^{*} \\
(0.0256)\end{array}$ & $\begin{array}{l}-0.0162 \\
(0.0326)\end{array}$ \\
\hline$\beta_{b}^{\text {Contizenew }}$ & $\begin{array}{l}-0.014 \\
(0.0791)\end{array}$ & $\begin{array}{c}-0.1166 \\
(0.0843)\end{array}$ & $\begin{array}{l}0.0113 \\
(0.0732)\end{array}$ & $\begin{array}{l}-0.1257 \\
(0.0817)\end{array}$ & $\begin{array}{l}-0.0495 \\
(0.0808)\end{array}$ & $\begin{array}{l}-0.0945 \\
(0.0722)\end{array}$ & $\begin{array}{c}0.0113 \\
(0.0662)\end{array}$ & $\begin{array}{l}-0.1277 \\
(0.0863)\end{array}$ & $\begin{array}{l}-0.0176 \\
(0.0692)\end{array}$ & $\begin{array}{l}-0.1165 \\
(0.0719)\end{array}$ \\
\hline$\beta_{b}^{\text {Alming }}$ & $\begin{array}{l}-0.026 \\
(0.0284)\end{array}$ & $\begin{array}{c}0.0176 \\
\{0.0288)\end{array}$ & $\begin{array}{l}-0.0257 \\
(0.0261)\end{array}$ & $\begin{array}{c}0.0304 \\
(0.0287)\end{array}$ & $\begin{array}{l}-0.0105 \\
(0.0295)\end{array}$ & $\begin{array}{l}-0.0138 \\
(0.0259)\end{array}$ & $\begin{array}{l}-0.0245 \\
(0.0237)\end{array}$ & $\begin{array}{l}0.0195 \\
(0.0291)\end{array}$ & $\begin{array}{l}-0.0135 \\
(0.0251)\end{array}$ & $\begin{array}{l}-0.0004 \\
(0.0264)\end{array}$ \\
\hline LIQUID & & & $\begin{array}{c}-0.1083 * * * \\
(0.0379)\end{array}$ & $\begin{array}{c}-0.0037 * \\
(0.002)\end{array}$ & & & & & $\begin{array}{l}0.0326 \\
(0.0609)\end{array}$ & $\begin{array}{l}-0.0028 \\
(0.0017)\end{array}$ \\
\hline SIZE & & & & & $\begin{array}{l}0.6672 \\
(0.4201)\end{array}$ & $\begin{array}{c}0.4185^{* * *} \\
(0.1093)\end{array}$ & & & $\begin{array}{l}0.4685 \\
(0.3605)\end{array}$ & $\begin{array}{r}0.3994^{4 * * *} \\
(0.1082)\end{array}$ \\
\hline SUPPLY & & & & & & & $\begin{array}{c}-0.5077^{* * *} \\
(0.1194)\end{array}$ & $\begin{array}{l}-0.0274 \\
(0.0388)\end{array}$ & $\begin{array}{c}-0.5811^{* * * *} \\
(0.2125)\end{array}$ & $\begin{array}{c}-0.0349 \\
(0.0322)\end{array}$ \\
\hline
\end{tabular}

Notes: ${ }^{* * *}$ indicates significant at the $1 \%$ level, ${ }^{* *}$ at $5 \%$ level, and ${ }^{*}$ at $10 \%$ level, all using two-tailed tests. 


\section{Conclusion}

Several groups of explanations have been proposed for the B-share discount puzzle. However, little attention has been paid to the explanatory power of different systematic risks in A- and B-shares (a notable exception is $\mathrm{Ma}, 1996$ ). This study examines the role that systematic risk plays in explaining the cross-sectional variation in B-share discounts using both cross-sectional analysis and panel data analysis, along with competing hypotheses.

Results show strong evidence that variations in A-share systematic risk is significantly correlated with those in B-share discounts, after controlling for various competing explanations. No evidence shows that variations in B-share systematic risk explain those in B-share discount.

After controlling for the equilibrium pricing effect, this study finds evidence to support the information asymmetry hypothesis and the differential demand hypothesis, but not the liquidity hypothesis.

\section{Acknowledgements}

John Qi Zhu acknowledges this research is supported by the National Science Foundation of China, No.71001069.

\section{References}

Andersen, T.G., Bollerslev, T., Diebold, F.X. and Labys, P. (2003) 'Modeling and forecasting realized volatility', Econometrica, Vol. 71, No. 2 , pp.579-625.

Bailey, W. (1994) 'Risk and return on China's new stock markets: some preliminary evidence', Pacific-Basin Finance Journal, Vol. 2, Nos. 2/3, pp.243-260.

Bailey, W. and Jagtiani, J. (1994) 'Foreign ownership restrictions and stock prices in the Thai capital market', Journal of Financial Economics, Vol. 36, No. 1, pp.57-87.

Barndorff-Nielsen, O.E. and Shephard, N. (2004) 'Power and bipower variation with stochastic volatility and jumps', Joumal of Financial Econometrics, Vol. 2, No. 1, pp.1-37.

Barndorff-Nielsen, O.E. and Shephard, N. (2006) 'Econometrics of testing for jumps in financial economics using bipower variation', Journal of Financial Econometrics, Vol. 4, No. 1, pp.1-30

Chakravarty, S., Sarkar, A. and Wu, L. (1998) 'Information asymmetry, market segmentation and the pricing of cross-listed shares: theory and evidence from Chinese A and B shares', Joumal of International Financial Markets, Institutions and Money, Vol. 8, Nos. 3/4, pp.325-356.

Chan, K. and Kwok, J.K.H. (2005) 'Market segmentation and share price premium', Journal of Emerging Market Finance, Vol. 1, pp.43-61.

Chan, K., Menkveld, A.J. and Yang, Z. (2007) 'The informativeness of domestic and foreign investors' stock trades: evidence from the perfectly segmented Chinese market', Journal of Financial Markets, Vol. 4, pp.391-415.

Chan, K., Menkveld, A.J. and Yang, Z. (2008) 'Information asymmetry and asset prices: evidence from the China foreign share discount', Joumal of Finance, Vol. 63, No. 1, pp.159-196.

Chen, G-M., Lee, B-S. and Rui, O.M. (2001) 'Foreign ownership restrictions and market segmentation in China's stock markets', Journal of Financial Research, Vol. 24, No. 1, pp.133-155. 
Chen, Z. and Xiong, P. (2001) Discounts on Illiguid Stocks: Evidence from China, Working Paper, Yale School of Management.

Chui, A.C.W. and Kwok, C.C.Y. (1998) 'Cross-autocorrelation between A-shares and B-shares in the Chinese stock market', Journal of Financial Research, Vol. 21, No. 3, pp.333-353.

Colwell, D., Liu, Y. and Sim, A.B. (2007) The Effect of Intangible Assets on Jumps in Stock Returns, Technical Report, The University of New South Wales.

Dunham, L.M. and Friesen, G.C. (2007) 'An empirical examination of jump risk in U.S. equity and bond markets', North American Actuarial Joumal, Vol. 11, No. 4, pp.76-91.

Fernald, J. and Rogers, J.H. (2002) 'Puzzles in the Chinese stock market', Review of Economics and Statistics, Vol. 84, No. 3, pp.416-432.

Hansen, P.R. and Lunde, A. (2006) 'Realized variance and market microstructure noise', Journal of Business and Economic Statistics, Vol. 24, pp.127-161.

Hietala, P.T. (1989) 'Asset pricing in partially segmented markets: evidence from the Finnish market', Journal of Finance, Vol. 44, No. 3, pp.697-718.

Kang, J-K. and Stulz, R.M. (1997) 'Why is there a home bias? An analysis of foreign portfolio equity ownership in Japan', Journal of Financial Economics, Vol, 46, No. 1, pp.3-28.

Kutan, A. and Zhou, H. (2006) 'Determinants of returns and volatility of Chinese ADRs at NYSE', Journal of Multinational Financial Management, Vol. 16, No. 1, pp.1-15.

Ma, X. (1996) 'Capital controls, market segmentation and stock prices: evidence from the Chinese stock market', Pacific-Basin Finance Journal, Vol. 4, Nos. 2/3, pp.219-239.

Mei, J., Scheinkman, J, and Xiong, W. (2009) 'Speculative trading and stock prices: evidence from Chinese A-B share premia', Annals of Economics and Finance, Vol. 10, No. 2, pp.225-255.

Sjoo, B. and Zhang, J. (2000) 'Market segmentation and information diffusion in China's stock markets', Journal of Multinational Financial Management, Vol. 10, Nos. 3/4, pp.421-438.

Sun, Q. and Tong, W.H.S. (2000) 'The effect of market segmentation on stock prices: the China syndrome', Journal of Banking \& Finance, Vol. 24, No. 12, pp. 1875 1902.

Yang, T. and Lau, S.T. (2005) 'U.S. cross-listing and China's B-share discount', Journal of Multinational Financial Management, Vol. 15, Nos. 4/5, pp.334-353.

Zhou, H., Geppert, J. and Kong, D. (2010) 'An anatomy of trading strategies: evidence from China', Emerging Markets Finance and Trade, Vol. 46, No. 2, pp.66-79.

Zhou, H. and Zhu, Q. (2012a) 'An empirical examination of jump risk in asset pricing and volatility forecasting in China's equity and bond markets', Pacific-Basin Finance Journal, Vol. 20 , No. 5 , pp. $857-880$.

Zhou, H. and Zhu, Q. (2012b) 'Jump on the post earnings announcement drift', Financial Analyst Journal, Vol. 68 , No. 3 , pp.63-80.

\section{Notes}

1 Before the regulatory change in February 2001, domestic investors were not allowed to owner and trade B-shares that were exclusively available to foreigners. After the regulatory change, the restriction is partially released to allow the ownership and trading of B-shares by domestic investors. Starting from 2006, Qualified Foreign Institutional Investors (QFII) were allowed to participate in the A-shares market but with strict up-limit on the total investment.

2 Market-wide institutional evolution regarding the investors access to the A- and B-share markets also implies that the actual compositions of investors in two markets are more homogeneous than what the statutory regulations specified even since the initiation of the dual market.

3 The discussion in this section is largely drawn from Dunham and Friesen (2007). 